\title{
Weryfikacja modeli konstrukcyjnych pozycjonerów spawalniczych w oparciu o modelowanie matematyczne MES
}

\author{
Verification of construction models of welding positioners \\ based on FEM mathematical modeling
}

\section{Streszczenie}

Wieloosiowy pozycjoner przeznaczony do zintegrowania z robotem przemysłowym powinien cechować się szerokim zakresem ruchów poszczególnych osi i możliwie jak największą przestrzenią roboczą, zdolnością do przenoszenia dużych momentów obciążających czy wysoką powtarzalnością pozycjonowania. Przedstawione wymagania stają nierzadko w sprzeczności. Opracowanie takiej konstrukcji wymaga szeregu kompromisów popartych analizami potrzeb, możliwości wytwórczych oraz akceptowalnej ceny urządzenia. W żadnym jednak wypadku dochodzenie do ostatecznego rozwiązania nie może być prowadzane wyłącznie w oparciu o intuicję konstruktora. Jednym z uznanych sposobów weryfikacji modeli konstrukcyjnych jest zastosowanie analizy wytrzymałościowej metodą elementów skończonych (MES). W artykule przedstawiono efekty prowadzonych prac badawczo-rozwojowych związanych z budową i wdrożeniem w PPU „ZAP Robotyka" w Ostrowie Wielkopolskim trzech nowych typów maszyn pozycjonujących.

Słowa kluczowe: pozycjoner spawalniczy; manipulator; analiza metoda elementów skończonych (MES)

\section{Abstract}

A multi-axis positioner designed for integration with an industrial robot should be characterized by a wide range of movements of individual axes and as much as possible working space, the ability to carry large loading moments or high repeatability of positioning. The presented requirements are often contradictory. The development of such a structure requires a number of compromises supported by needs analysis, production capabilities and an acceptable price of the device. However, in no case may the investigation of the final solution be carried out solely on the basis of the constructor's intuition. One of the recognized methods of verification of structural models is the application of strength analysis using the finite element method (FEM). The article presents the results of research and development works related to the construction and implementation of three new types of positioning machines in PPU "ZAP Robotyka" in Ostrów Wielkopolski.

Keywords: welding positioner; manipulator; finite element analysis (FEM)

\section{Wprowadzenie}

Wieloosiowe pozycjonery manipulujące zamocowanymi obiektami, np. przeznaczonymi do spawania, stanowią jedną z najważniejszych grup maszyn integrowanych z robo-

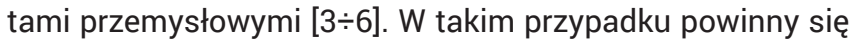
cechować m.in. szerokim zakresem ruchów poszczególnych osi i możliwie jak największą przestrzenią roboczą (obszarem załadunkowym), zdolnością do przenoszenia możliwie jak największych momentów obciążających czy wysoką powtarzalnością pozycjonowania, najlepiej tego samego rzędu co współpracujących robotów. Przedstawione wymagania stają nierzadko w sprzeczności, np. długie ramiona manipulacyjne zapewniając dużą przestrzeń roboczą ograniczą zdolność załadunkową i mogą negatywnie wpłynąć na osiąganą powtarzalność pozycjonowania.

Opracowanie takiego pozycjonera wymaga szeregu kompromisów popartych analizami potrzeb technologicznych, możliwości wytwórczych (dostępność materiałów, napędów i przekładni) oraz akceptowalnej ceny urządzenia. Dochodzenie do ostatecznego rozwiązania nie może być prowadzane wyłącznie w oparciu o doświadczenie i intuicję konstruktora. Jednym z uznanych sposobów weryfikacji modeli konstrukcyjnych jest zastosowanie matematycznej analizy wytrzymałościowej metodą elementów skończonych (MES) $[1 \div 4,7]$.

Dr inż. Paweł Cegielski; dr hab. inż. Dariusz Golański, prof. PW; dr inż. Paweł Kołodziejczak; prof. dr hab. inż. Andrzej Kolasa; mgr inż. Damian Rochalski - Politechnika Warszawska, dr inż. Tadeusz Sarnowski - ZAP Robotyka Ostrów Wlkp.

Autor korespondencyjny/Corresponding author. pcegiels@wip.pw.edu.pl 
W ramach prowadzonych prac badawczo-rozwojowych opracowano modele konstrukcyjne CAD trzech nowych typów maszyn - dwóch typoszeregów wieloosiowych pozycjonerów, o konstrukcji typu "L" i „ $\mathrm{H}^{\prime}$, oraz systemu torów jezdnych, zapewniających robotom niezbędną w takich przypadkach lokomocję (rys. $1 \div 3$ ) $[5,11]$.

Przy projektowaniu poszczególnych modeli konstrukcyjnych CAD korzystano z wyników wstępnego studium zależności materiałowych i konstrukcyjnych, przeprowadzonego metodą elementów skończonych MES dla wytypowanych belek konstrukcyjnych [5]. Kolejny etap prac projektowych i badawczych dotyczyło statecznej weryfikacji gotowych modeli konstrukcyjnych w oparciu o analizę wytrzymałościową metodą elementów skończonych i obejmował następujące zagadnienia [9]:

1. Opracowanie modeli bazowych do modelowania MES poszczególnych pozycjonerów i torów jezdnych, w tym:

a. ustalenie rodzaju i gęstości siatki MES,

b. wytypowanie sposobu przygotowania modeli konstrukcyjnych CAD, w tym usunięcie elementów rysunkowych, części lub podzespołów nieistotnych, utrudniających modelowanie,

c. ewentualne wyodrębnienie reprezentatywnej części konstrukcji do modelowania.

2. Ustalenie rodzaju, charakteru i zakresu obciążeń statycznych i dynamicznych, działających na modelowane zespoły.

3. Obliczenia i wizualizacje powstających ugięć, sił wzdłużnych, poprzecznych i momentów zginających badanych modeli konstrukcyjnych.

4. Przekazanie wniosków z modelowania MES do weryfikacji modeli konstrukcyjnych CAD poszczególnych pozycjonerów i torów jezdnych.

Badania obliczeniowe metodą elementów skończonych prowadzone były z wykorzystaniem specjalistycznego programu matematycznego LUSAS FEA [8]. W artykule przedstawiono wybrane wyniki badań pozycjonera typu "L", charakteryzującego się największą złożonością kinematyczną, a zatem stanowiącego największe wyzwanie od strony obliczeniowej i konstrukcyjnej. a)
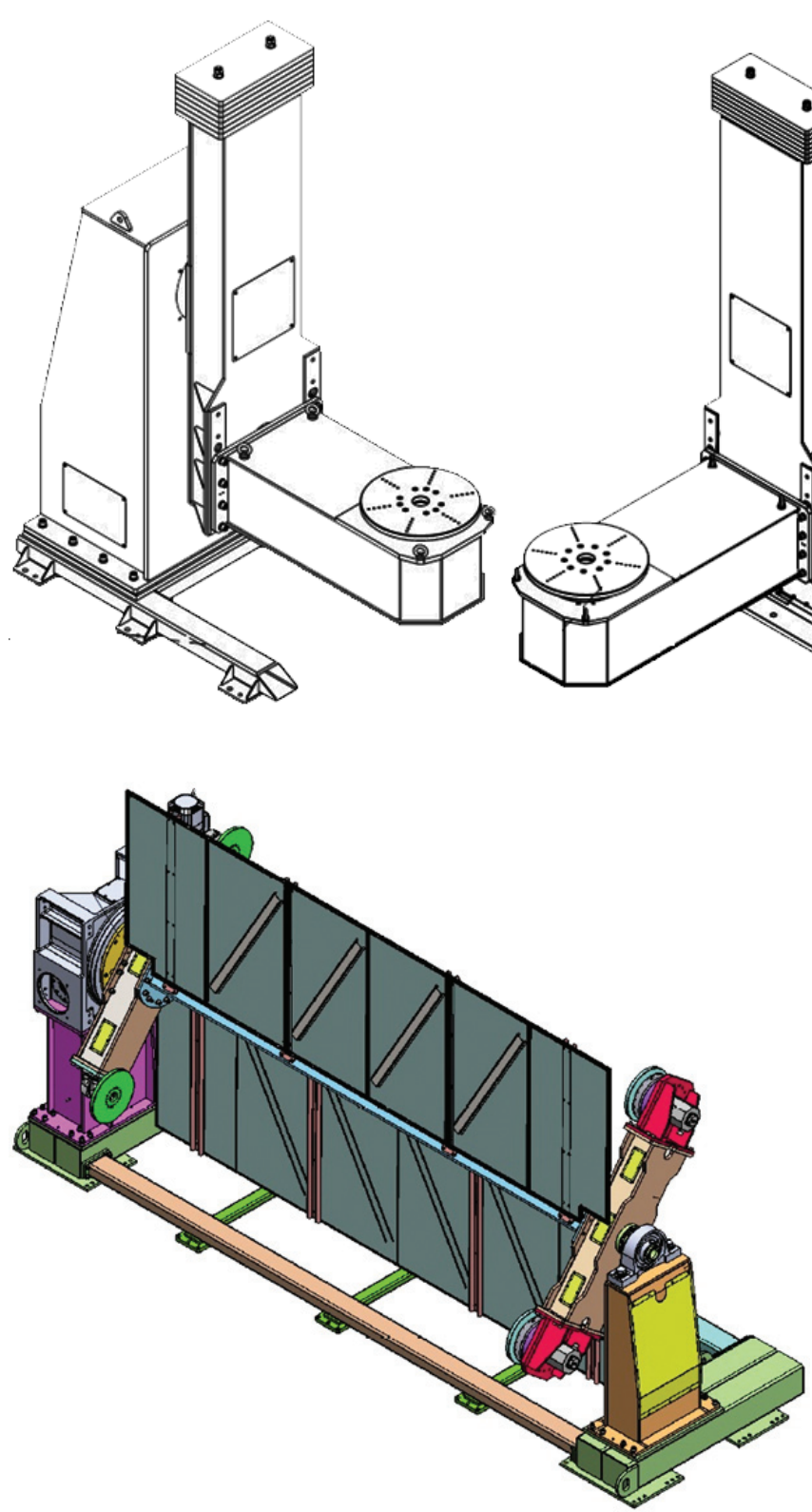

Rys. 2. Przykładowy model konstrukcyjny CAD trzyosiowego pozycjonera typu "H" o nośności $1000 \mathrm{~kg}$

Fig. 2. An example of CAD design model of a three-axis "H-type" positioner with a load capacity of $1000 \mathrm{~kg}$
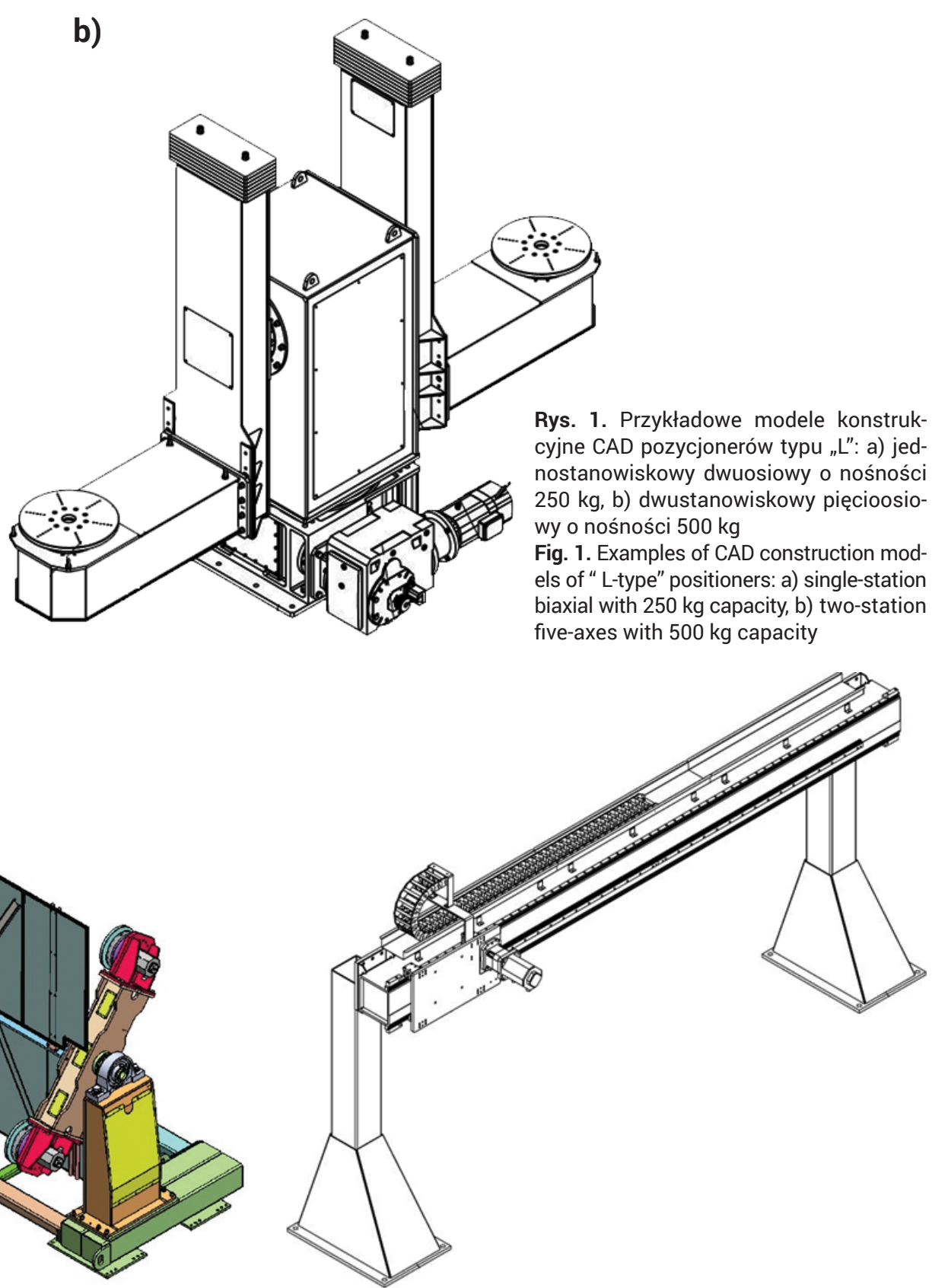

Rys. 3. Przykładowy model konstrukcyjny CAD toru jezdnego podwieszanego o długości $5 \mathrm{~m}$ i nośności $500 \mathrm{~kg}$

Fig. 3. An example of CAD construction model of a suspended track with a length of $5 \mathrm{~m}$ and a load capacity of $500 \mathrm{~kg}$ 


\section{Opracowanie modeli bazowych do modelowania MES}

Modelem bazowym był pozycjoner jednostanowiskowy typu L przedstawiony na rysunku 4 . Założono, że pozycjoner zaprojektowany będzie dla dwóch obciążeń (nośności) $250 \mathrm{~kg}$ oraz $500 \mathrm{~kg}$. Z uwagi na dość dużą złożoność geometryczną modelu pozycjonera przeprowadzono wstępne modelowanie mające na celu określenie odpowiedniej liczby elementów skończonych, które tworzyć będą przestrzenną siatkę elementów skończonych niezbędną do przeprowadzenia obliczeń. W tym celu zbudowano szereg identycznych modeli pozycjonera typu L obciążonego masą $250 \mathrm{~kg}$, w których stopniowo zagęszczano siatkę zwiększając całkowitą liczbę elementów skończonych od ok. 28000 aż do prawie 800000. Dla każdego wariantu wykonano obliczenia pod zadanym obciążeniem, dla których zanotowano maksymalne wartości ugięcia (przemieszczenia) pionowego belki poprzecznej w miejscu obciążenia oraz maksymalne wartości naprężenia zredukowanego $\mathrm{w}$ konstrukcji pozycjonera. Zestawienie tak wyznaczonych wartości zaprezentowano w tablicy I. Widać, że wzrost liczby elementów skończonych modelu powyżej 100000 prowadzi już do bardzo niewielkiego wzrostu ugięcia pionowego końca belki poprzecznej. Z kolei naprężenie zredukowane stabilizuje się dla ok. $100000 \div 200000$ elementów, po czym dalej wzrasta ze wzrostem liczby elementów. W przypadku modelowania MES często występuje zbieżność jednego parametru (w tym przypadku przemieszczenia), oraz rozbieżność drugiego parametru (naprężenia). Jest to zazwyczaj spowodowane osobliwościami, które często pojawiają się w modelach MES.

W celu zachowania kompromisu między liczbą elementów skończonych a wyznaczonymi wartościami przyjęto do dalszych obliczeń i analiz model ze 128979 elementami skończonymi, dla którego wartość ugięcia pionowego nie różni się już znacząco od wartości dla modeli z coraz większą liczbą elementów skończonych.

a)

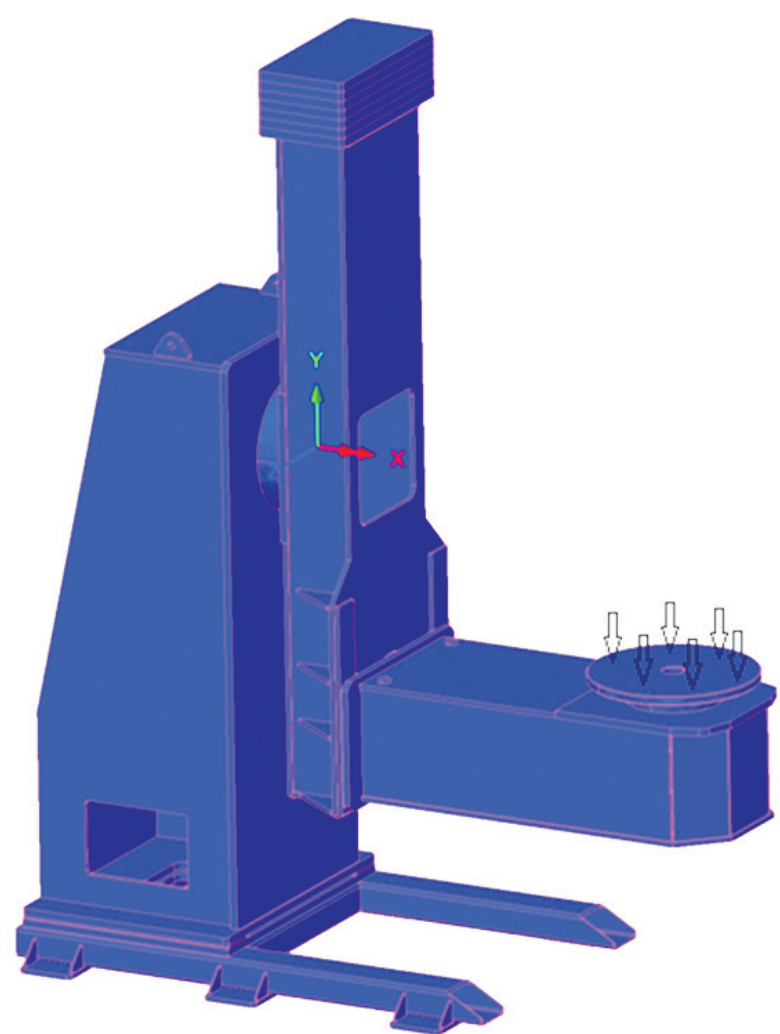

Tablica I. Wpływ liczby elementów skończonych na wielkość maksymalnego ugięcia pionowego oraz naprężenia zredukowanego w modelu pozycjonera typu $\mathrm{L}$

Table I. Influence of the number of finite elements on the size of the maximum vertical deflection and effective stress in the L-type positioner model

\begin{tabular}{|c|c|c|}
\hline $\begin{array}{c}\text { Ilość elementów } \\
\text { skończonych }\end{array}$ & $\begin{array}{c}\text { Przemieszczenie } \\
\text { pionowe [mm] }\end{array}$ & $\begin{array}{c}\text { Naprężenie zredu- } \\
\text { kowane [MPa] }\end{array}$ \\
\hline 28313 & 0,944 & 20,46 \\
\hline 37169 & 1,023 & 23,147 \\
\hline 53020 & 1,086 & 22,146 \\
\hline 90299 & 1,14 & 29,791 \\
\hline 128979 & 1,17 & 31,349 \\
\hline 206612 & 1,19 & 31,168 \\
\hline 441438 & 1,22 & 41,151 \\
\hline 799226 & 1,23 & 44,83 \\
\hline
\end{tabular}

\section{Wyniki obliczeń dla pozycjonera jednostanowiskowego typu L przy obciążeniu masą 250 i $500 \mathrm{~kg}$}

Dla przyjętej geometrii konstrukcji pozycjonera przestrzennego oraz dobranym zagęszczeniu siatki elementów skończonych przeprowadzono obliczenia numeryczne uzyskując informacje o miejscach spiętrzenia naprężeń oraz największego ugięcia konstrukcji pod obciążeniem.

Na rysunku 5 przedstawiono wizualizację ugięcia pionowego pozycjonerów L dla przyjętych obciążeń. Widoczny jest ponad dwukrotny wzrost ugięcia końca pionowej belki poprzecznej z 1,16 mm dla obciążenia $250 \mathrm{~kg}$ do 3,24 $\mathrm{mm}$ dla obciążenia 500 kg. Widać także, że kształt belki poprzecznej

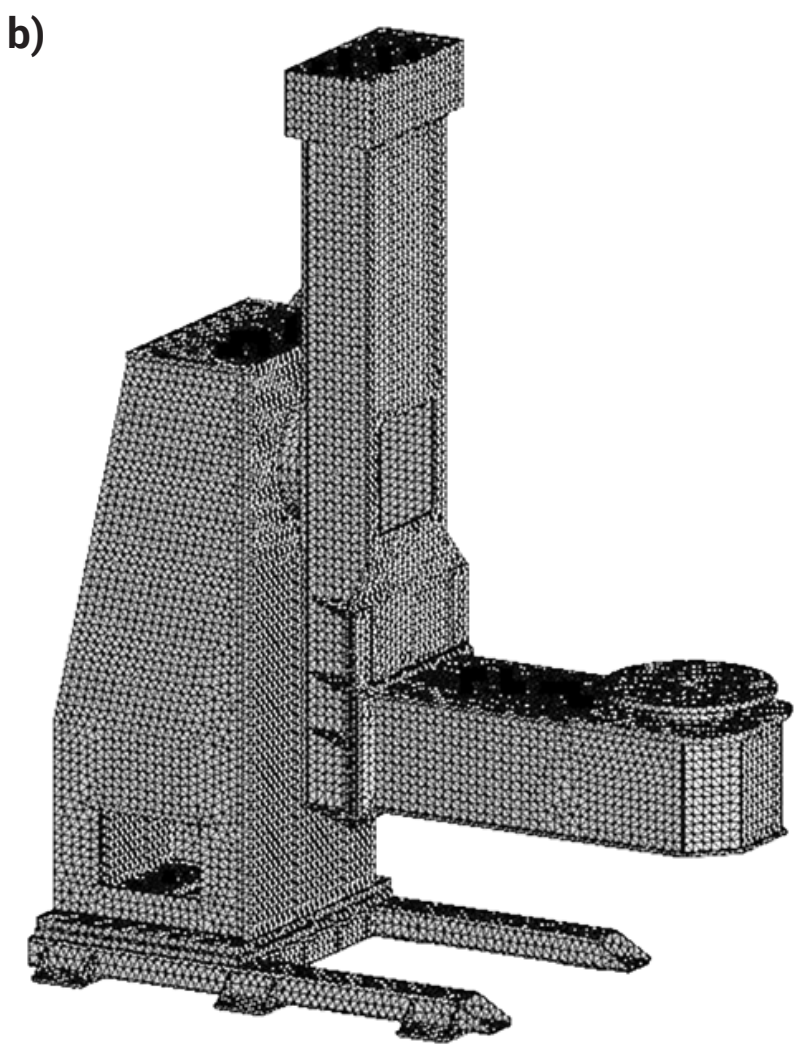

Rys. 4. Pozycjoner podstawowy typu L: a) widok geometrii modelu, b) model z naniesioną siatką elementów (3D) skończonych do analizy wytrzymałościowej za pomocą MES

Fig. 4. L-type basic positioner. a) model geometry view, b) model with a grid of finite elements (3D) for strength analysis using MES 

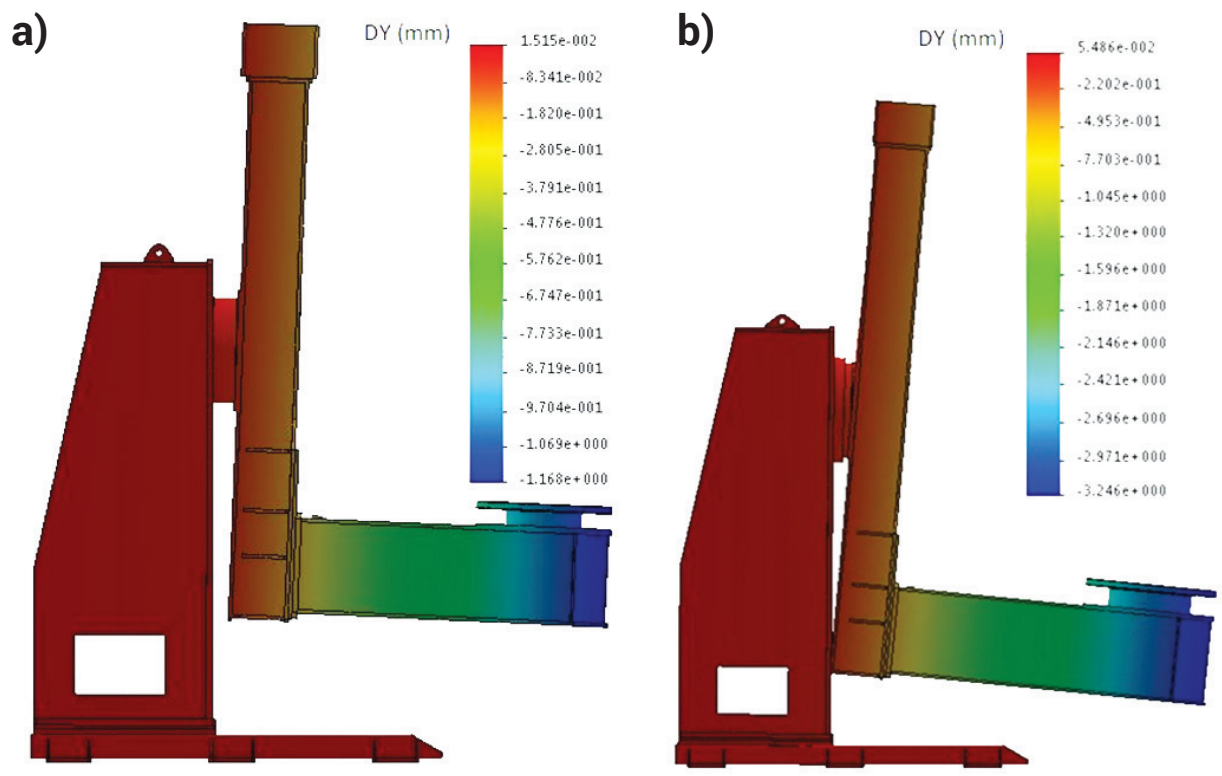

Rys. 5. Wizualizacja ugięcia pionowego pozycjonera typu L: a) pod obciążeniem $250 \mathrm{~kg}$, b) pod obciążeniem $500 \mathrm{~kg}$

Fig. 5. Visualization of the vertical deflection of the L-type positioner. a) under a load of $250 \mathrm{~kg}, \mathrm{~b}$ ) under a load of $500 \mathrm{~kg}$

oraz połączonej z nią belki pionowej praktycznie nie uległ odkształceniu a jedynie doznał obrotu o pewien kąt względem miejsca połączenia belki pionowej z korpusem pozycjonera, co świadczy o tym, że jest to obszar decydujący o wielkości ugięcia pionowego belki poprzecznej pozycjonera.

Na rysunku 6 pokazano rozkład naprężenia zredukowanego w modelu pozycjonera typu $L(250 \mathrm{~kg})$. Wartości maksymalne naprężeń koncentrują się w obszarze połączenia belki pionowej z korpusem i osiągają wartości ok. $31 \mathrm{MPa}$ dla modelu z obciążeniem $250 \mathrm{~kg}$ oraz $109 \mathrm{MPa}$ dla modelu z obciążeniem $500 \mathrm{~kg}$. Jest to miejsce, które wydaje się kluczowe z punktu widzenia ugięcia pionowego belki poziomej pozycjonera, ponieważ tam właśnie dochodzi do obrotu pionowej belki względem osi poziomej tulei łączącej korpus z belką pionową.
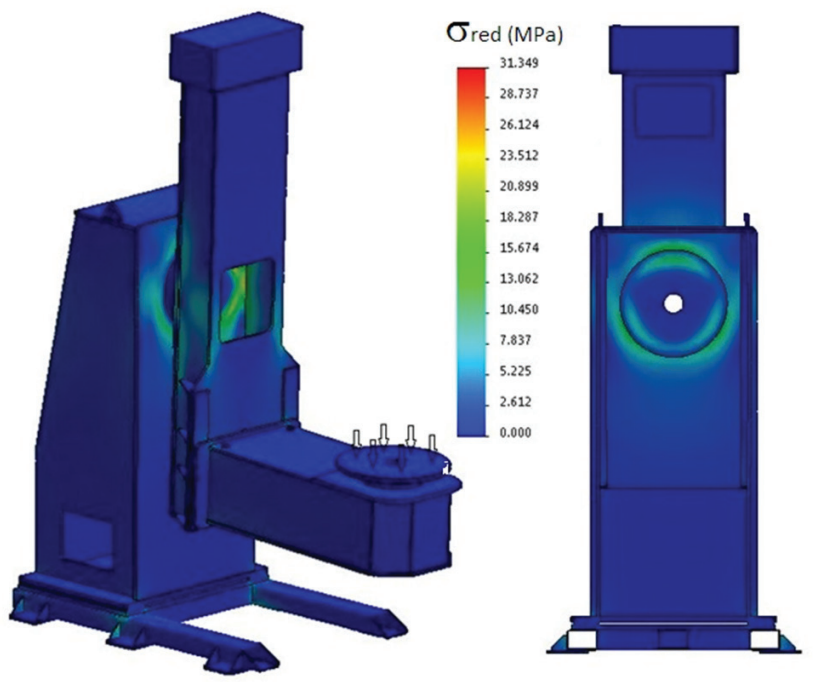

Rys. 6. Rozkład naprężeń zredukowanych w modelu pozycjonera typu-L $(250 \mathrm{~kg})$ obliczony za pomocą MES

Fig. 6. Distribution of effective stresses in the L-type positioner $(250 \mathrm{~kg})$ calculated using FEM

\section{Ustalenie obciążeń statycznych i dynamicznych}

Pozycjonery typu „L" manipulują obiektami za pośrednictwem dwóch osi głównych - obrotowego stołu i ramienia w kształcie litery "L" (rys. 1), na którym stół jest zamocowany. Pochodną manipulacji za pośrednictwem długiego, obrotowego ramienia „L" jest wysoka funkcjonalność - najlepsze usytuowanie manipulowanego obiektu w stosunku do zasięgu robota i w pełni użyteczny, pełny zakres pochylenia obiektu aż do pozycji całkowicie obróconej [9]. Dodatkowo pojawia się możliwość naturalnego wyważenia manipulowanego obiektu poprzez zbliżenie jego środka ciężkości do osi obrotu ramienia "L", wspomagane zmienną przeciwwagą (rys. 7).

W celu uzyskania wysokich walorów użytkowych przyjęto dwa rozmiary przestrzeni roboczej w formie sześcianu, nieruchomo usytuowanego przed korpusem pozycjonera i postawionego na powierzchni stołu roboczego znajdującego się w dolnym, najniższym położeniu, wewnątrz którego może znaleźć się manipulowany obiekt: 1,5 x 1,5 x 1,5 m (dla nośności $250 \mathrm{~kg}$ ) i 2,0 x 2,0 x 2,0 m (dla $500 \mathrm{~kg}$ ). Wymusiło to znaczne rozmiary wysuniętych belek zakończonych stołem roboczym, poddawanych silnym naprężeniom i potencjalnym odkształceniom (rys. 8).

W projekcie założono, że nośność (udźwig) nominalna dostępna będzie w punkcie znajdującym się na środku powierzchni montażowej stołu roboczego pozycjonera lub platformy jezdnej robota i będzie maleć w miarę odsuwania się

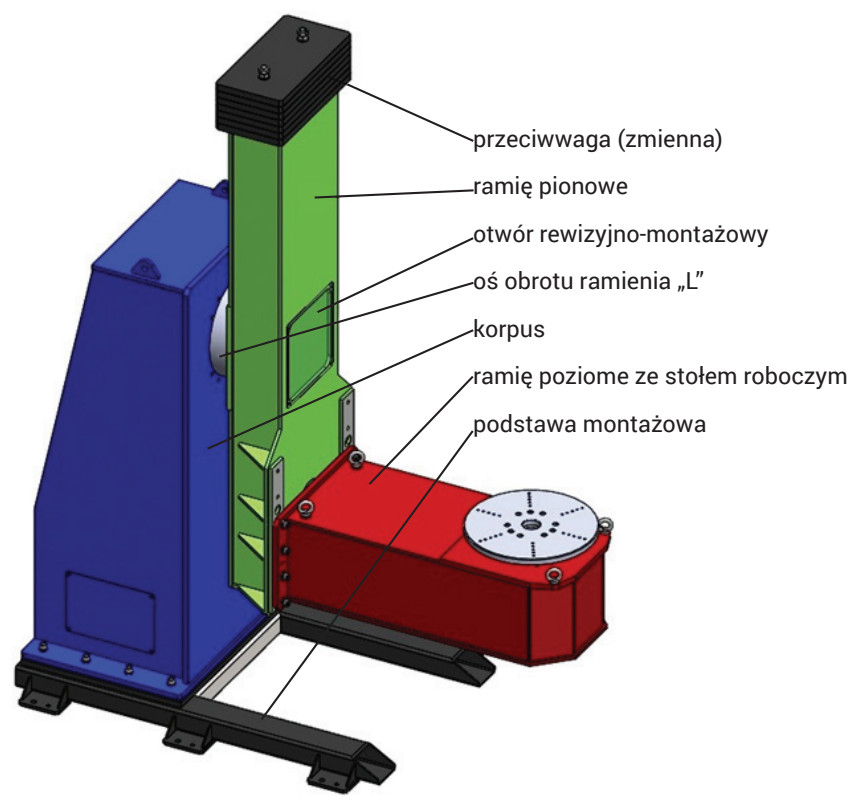

Rys. 7. Widok ogólny i główne podzespoły modelu pozycjonera typu "L" (250 kg)

Fig. 7. General view and main parts of the L-type positioner $(250 \mathrm{~kg})$ 


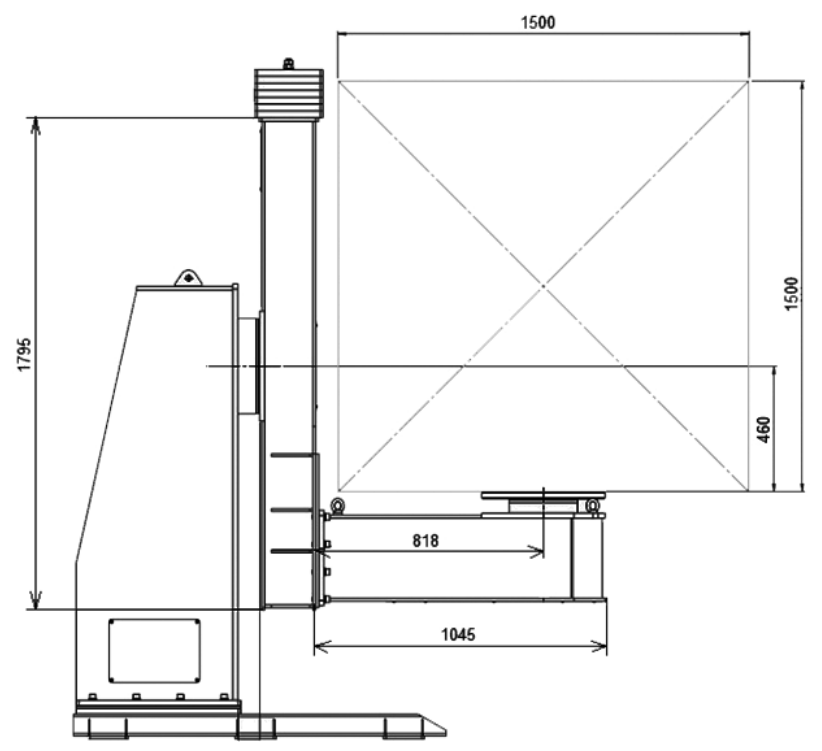

Rys. 8. Główne wymiary modelu pozycjonera typu "L" (250kg) Fig. 8. Main dimensions of the L-type positioner $(250 \mathrm{~kg})$

środka ciężkości obciążenia. Z uwagi na bardzo małe prędkości manipulacji (nieprzekraczające pojedynczych obrotów na minutę), analizy dotyczyły obciążeń statycznych przykładanych na powierzchni stołu. Inaczej w przypadku opracowanych modeli konstrukcyjnych torów jezdnych, wysokie prędkości ruchów robota wymuszają analizę dynamiczną.

Specyficzna konstrukcja tego typu pozycjonera sprawia, że obciążenie ramion i napędów będzie się znacząco różniło w zależności od chwilowego położenia osi obrotu ramienia „L". Należało zatem wyodrębnić i poddać analizie ustawienia reprezentujące najtrudniejsze warunki pracy - w pozycji podstawowej (A na rys. 9), bocznej (B na rys. 9) i odwróconej (C na rys. 9).

Jednocześnie, dla zweryfikowanego modelu możliwe będzie odsunięcie miejsca przyłożenia obciążenia od powierzchni stołu i od osi jego obrotu, symulujące zróżnicowane położenie środka ciężkości rzeczywistego obiektu, i sprawdzenie charakterystyki obciążeniowej pozycjonera.

Na rysunku 10 przedstawiono wyniki rozkładu naprężeń zredukowanych oraz ugięcia pionowego $\mathrm{w}$ pozycjonerze $\mathrm{L}$ obciążonym masą $500 \mathrm{~kg}$ w ustawieniu ramienia poziomego odwróconego o $180^{\circ} \mathrm{W}$ stosunku do modelu podstawowego.

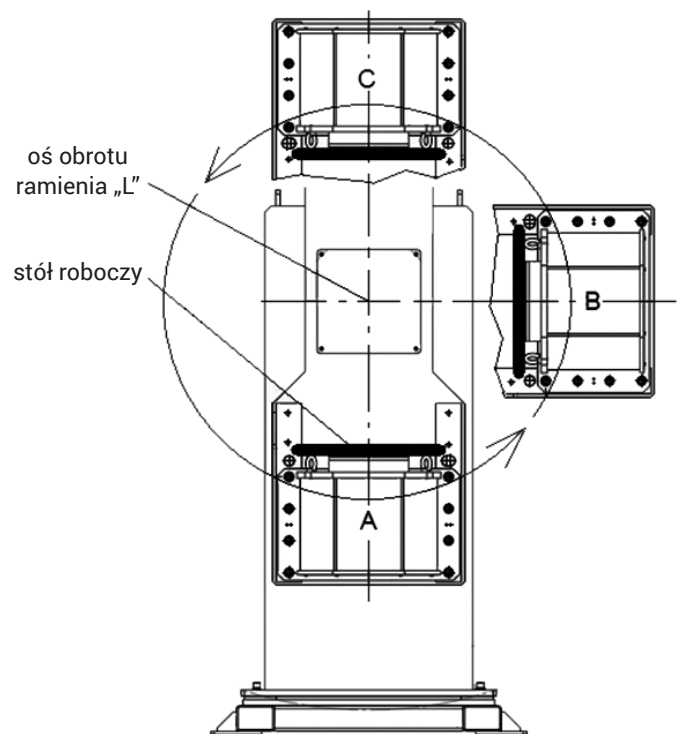

Rys. 9. Analizowane ustawienia osi obrotu ramienia " $L$ " Fig. 9. Analyzed settings of the axis of rotation of the " $L$ " arm

Wyniki obliczeń pokazują, że model pozycjonera $L$ z ramieniem obróconym o $180^{\circ}$ nie wykazuje specjalnych różnic zarówno w rozkładzie naprężeń zredukowanych (wielkość maksymalna naprężenia wyniosła 108,4 MPa), jak i w przypadku przemieszczeń (maksymalne ugięcie pionowe wyniosło 3,26 mm) w stosunku do modelu podstawowego Interesujące informacje dostarczają wyniki obliczeń dla modelu pozycjonera z ramieniem ustawionym w pozycji obróconej o $90^{\circ}$ (rys. 11).

W tym przypadku widać, że dłuższe poziome ramię podlega skręcaniu, a naprężenie zredukowane wzrasta do $138,7 \mathrm{MPa}$. Maksymalne przemieszczenie pionowe DY dla konfiguracji " $90^{\circ}$ (2,90 mm) jest mniejsze niż dla konfiguracji podstawowej „ $0^{\circ \prime \prime}(3,25 \mathrm{~mm})$, choć wydaje się, że konfiguracja "90" powinna być najmniej korzystna pod tym względem. Wynika to jednak z połączenia konstrukcji "L" z korpusem, czyli miejscem, od którego w największym stopniu zależy wartość maksymalna przemieszczenia pionowego. W zadanej konfiguracji w tym miejscu połączenia występują różnice spowodowane usztywnieniem przez płytę, która się tam znajduje. Jej geometria/rozmiar może mieć

Tablica II. Wpływ liczby elementów skończonych na wielkość maksymalnego ugięcia pionowego oraz naprężenia zredukowanego w modelu pozycjonera typu L

Table II. Influence of the number of finite elements on the size of the maximum vertical deflection and effective stress in the L-type positioner model

\begin{tabular}{|c|c|c|c|}
\hline & & $\begin{array}{l}\text { Naprężenie zre- } \\
\text { dukowane [MPa] }\end{array}$ & $\begin{array}{c}\text { Przemieszczenie } \\
\text { pionowe [mm] }\end{array}$ \\
\hline \multicolumn{4}{|c|}{ Wersja podstawowa } \\
\hline \multirow{3}{*}{$\begin{array}{l}\text { Kąt obrotu } \\
\text { ramienia L }\end{array}$} & $0^{\circ}$ & 109,1 & 3,246 \\
\hline & $180^{\circ}$ & 108,4 & 3,261 \\
\hline & $90^{\circ}$ & 138,7 & 2,902 \\
\hline \multicolumn{4}{|c|}{ Wersja ze zwiększoną płytą } \\
\hline \multirow{3}{*}{$\begin{array}{l}\text { Kąt obrotu } \\
\text { ramienia L }\end{array}$} & $0^{\circ}$ & 98,3 & 3,054 \\
\hline & $180^{\circ}$ & 98,3 & 3,076 \\
\hline & $90^{\circ}$ & 122,6 & 2,868 \\
\hline \multicolumn{4}{|c|}{ Wersja bez otworu technologicznego } \\
\hline \multirow{3}{*}{$\begin{array}{l}\text { Kąt obrotu } \\
\text { ramienia L }\end{array}$} & $0^{\circ}$ & 110,1 & 3,173 \\
\hline & $180^{\circ}$ & 112,2 & 3,198 \\
\hline & $90^{\circ}$ & 117,3 & 2,584 \\
\hline
\end{tabular}

\begin{tabular}{|c|c|c|}
\hline & $\begin{array}{l}\text { Naprężenie zre- } \\
\text { dukowane [MPa] }\end{array}$ & $\begin{array}{l}\text { P rzemieszczenie } \\
\text { pionowe }[\mathrm{mm}]\end{array}$ \\
\hline \multicolumn{3}{|c|}{ Wersja podstawowa $90^{\circ}$} \\
\hline siła na pozycjonerze & 138,7 & 2,902 \\
\hline siła oddalona o $500 \mathrm{~mm}$ & 105,2 & 3,113 \\
\hline \multicolumn{3}{|c|}{ Wersja ze zwiększoną płytą $90^{\circ}$} \\
\hline siła na pozycjonerze & 122,6 & 2,868 \\
\hline siła oddalona o $500 \mathrm{~mm}$ & 100,1 & 3,07 \\
\hline \multicolumn{3}{|c|}{ Wersja bez otworu technologicznego $90^{\circ}$} \\
\hline siła na pozycjonerze & 117,3 & 2,584 \\
\hline siła oddalona o $500 \mathrm{~mm}$ & 107,1 & 2,71 \\
\hline
\end{tabular}


wpływ na wielkość maksymalnego ugięcia pionowego tarczy pozycjonera, choć jak wykazały obliczenia nie są to wartości znaczące.

W analizie konstrukcji pozycjonera $L$ istotne znaczenie ma także ustalenie środka ciężkości narzędzia/konstrukcji, która będzie zamocowana na tarczy obrotnika. Będzie to miało wpływ na wielkość momentu skręcającego krótszego ramienia pozycjonera. Układ optymalny będzie miał miejsce wtedy, gdy środek przyłożenia siły wystąpi w płaszczyźnie obrotnika. W rzeczywistości zawsze będzie on ulegał pewnemu przesunięciu w zależności od zamocowanego elementu. Taki przypadek został zaprezentowany na rysunku 12, w którym zasymulowano obciążenie $(500 \mathrm{~kg})$ przesunięte względem powierzchni tarczy obrotnika o $500 \mathrm{~mm}$. W takim układzie maksymalne ugięcie pionowe wzrosło z 2,90 mm do 3,11 mm przy niewielkim spadku naprężeń zredukowanych ze 138,7 do 105,2 MPa. Oprócz zwiększenia płyty, będącej w miejscu połączenia konstrukcji "L" z korpusem, dalsze nieznaczne obniżenie wielkości pionowego ugięcia ramienia pozycjonera z tarczą można uzyskać poprzez usunięcie prostokątnego otworu technologicznego, który znajduje się w drugim ramieniu łączącym całe ramię $L$ z korpusem pozycjonera. Dla takiego przypadku ustawienia pozycjonera przy obciążeniu $500 \mathrm{~kg}$ przesuniętym o $500 \mathrm{~mm}$ w stosunku do płaszczyzny tarczy obrotnika uzyskano obniżenie maksymalnego ugięcia z 3,11 mm do 2,71 mm (tabl. II).

W tablicy II zebrano wyniki obliczeń numerycznych naprężeń zredukowanych oraz przemieszczeń dla pozycjonera typu $L \mathrm{w}$ trzech różnych położeniach ramienia $z$ tarczą obrotnika $\left(0,90,180^{\circ}\right)$ oraz dla trzech wariantów konstrukcyjnych pozycjonera: dla wersji podstawowej, ze zmienioną wielkością płyty (powiększoną w stosunku do wyjściowej) w obszarze połączenia pozycjonera z korpusem oraz w wariancie bez prostokątnego otworu technologicznego $w$ dłuższym ramieniu pozycjonera. Zamieszczono także wyniki dla pozycjonera w pozycji obróconej o $90^{\circ}$ uwzględniające przesunięty o $500 \mathrm{~mm}$ środek działania obciążenia. a)
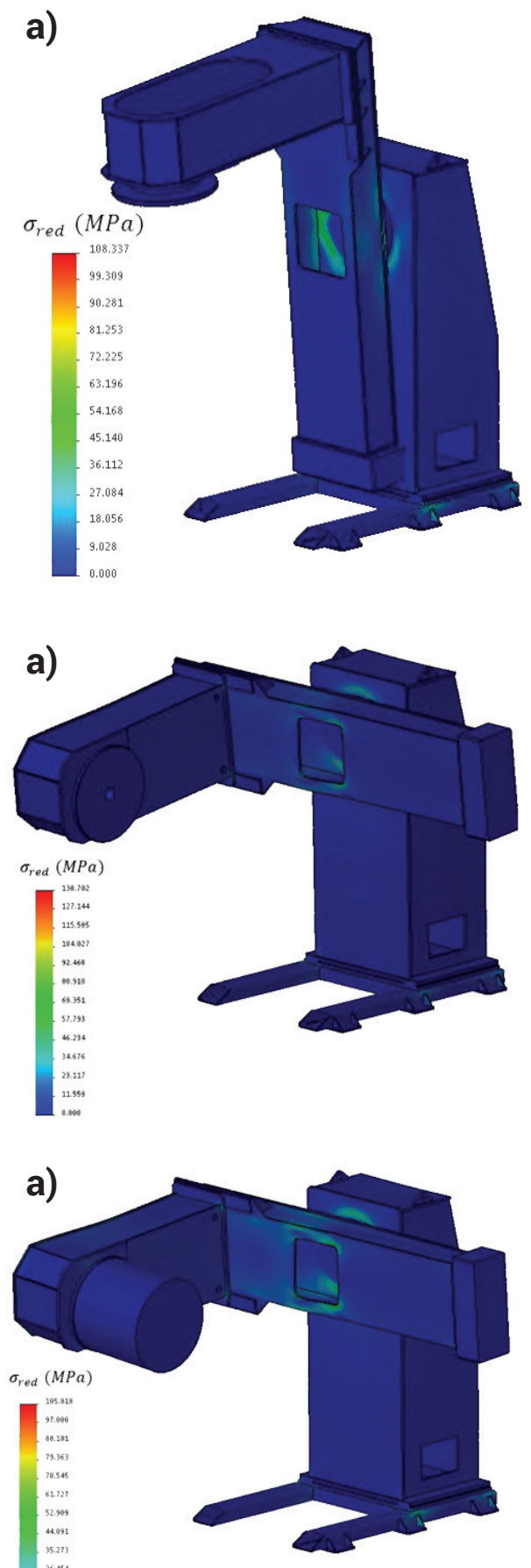

b)

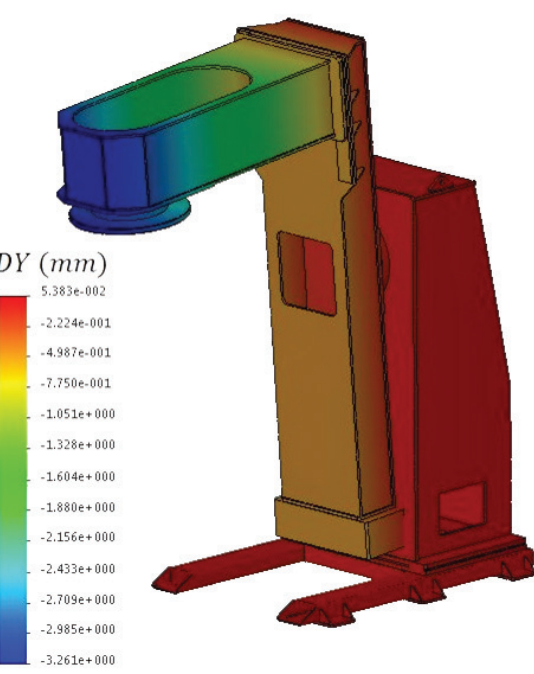

b)

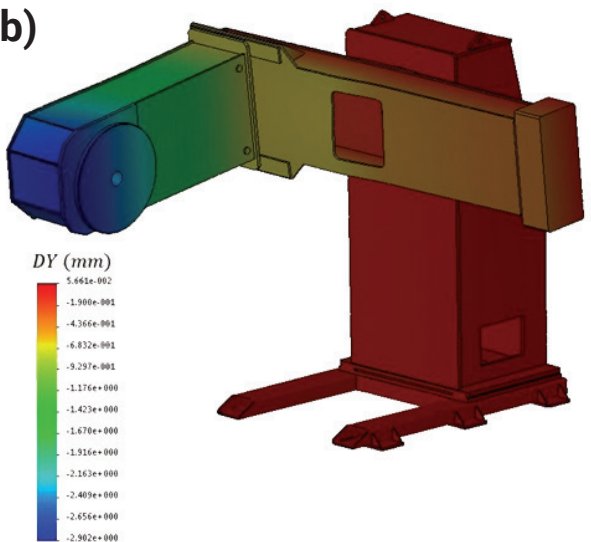

b)

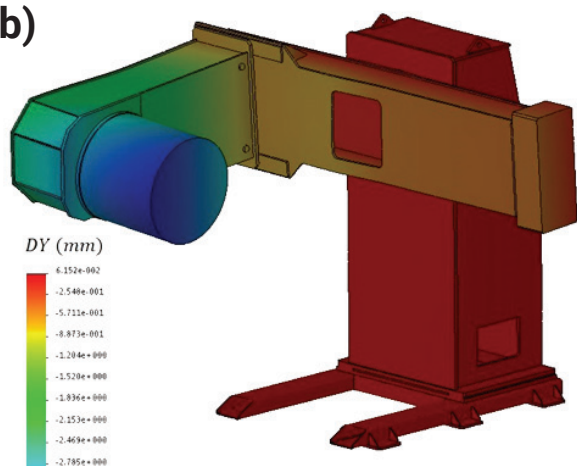

Rys. 10. Pozycjoner typu $L(500 \mathrm{~kg})$ w pozycji odwróconej $\left(180^{\circ}\right)$ : a) rozkład naprężeń zredukowanych, b) rozkład przemieszczenia (ugięcia) pionowego Fig. 10. L-type positioner $(500 \mathrm{~kg})$ in the inverted position $\left(180^{\circ}\right)$ : a) effective stress distribution, $b$ ) vertical displacement distribution (deflection)
Rys. 11. Pozycjoner typu $L(500 \mathrm{~kg})$ w pozycji obróconej o $90^{\circ}$ : a) rozkład naprężeń zredukowanych, b) rozkład przemieszczenia (ugięcia) pionowego Fig. 11. L-type positioner $(500 \mathrm{~kg})$ in the position rotated by $90^{\circ}$ : a) distribution of effective stresses, b) vertical displacement distribution (deflection)

Rys. 12. Pozycjoner typu $L(500 \mathrm{~kg})$ w pozycji obróconej o $90^{\circ} \mathrm{z}$ przesuniętym o $500 \mathrm{~mm}$ środkiem działania obciążenia: a) rozkład naprężeń zredukowanych, b) rozkład przemieszczenia (ugięcia) pionowego

Fig. 12. L-type positioner $(500 \mathrm{~kg})$ in the position rotated by $90^{\circ}$ with the center of load action offset by $500 \mathrm{~mm}$ : a) distribution of the effective stresses, $b$ ) vertical displacement distribution (deflections) 
Dla zadanych warunków pracy projektowanych pozycjonerów kryteriami podlegającymi ocenie było:

1. Osiągnięcie poziomu sił i momentów gnących, wywołującego naprężenia rozciągające lub ściskające w belkach nieprzekraczające granicy plastyczności materiału konstrukcyjnego, obliczonych w obszarze zamocowania do podłoża typoszeregu pozycjonerów „L" i „H" oraz słupów systemu modułowego torów jezdnych.

2. Osiągnięcie poziomu odkształceń sprężystych wywołujących ugięcia (deformacje) nieprzekraczające 0,05 mm obliczonych w obszarze stołów roboczych dla typoszeregu pozycjonerów "L" i „H" oraz dla belki jezdnej toru systemu modułowego torów jezdnych.
O ile warunek pierwszy można uznać za spełniony dla analizowanych pozycjonerów typu L, w których największe naprężenia zredukowane nie osiągały wartości połowy granicy plastyczności materiału to spełnienie kryterium ograniczenia wielkości ugięcia w miejscu mocowania w obszarze stołu wydaje się trudne do zapewnienia dla przyjętych rozwiązań i wielkości elementów konstrukcyjnych, z których zbudowany jest pozycjoner. Kluczowym miejscem wydaje się być obszar połączenia ramienia $L$ pozycjonera z jego korpusem. Analiza wykazała, że praktycznie głównie w tym miejscu dochodzi do ugięcia ramienia pozycjonera, które prowadzi do obrotu całego układu ramion typu L o pewien kąt. Potwierdzają to liniowe zmiany ugięcia pionowego wyznaczone wzdłuż całej długości końcowego ramienia pozycjonera L.

\section{Podsumowanie}

Konstrukcja pozycjonera przeznaczonego do zintegrowanej współpracy z robotem przemysłowym, cechującym się szerokim zakresem ruchów, dużą nośnością oraz przestrzenią roboczą jest zadaniem trudnym. Wynika to głównie z przyjętych założeń dotyczących podobnej powtarzalności pozycjonowania robota jak i pozycjonera. Wykonane obliczenia metodą MES pokazały, że dla pozycjonera typu "L” o nośności 500 kg możemy spodziewać się przemieszczeń w granicy 3 mm. Modyfikacja konstrukcji mająca na celu zwiększenia sztywności daje tylko nieznaczne efekty w postaci niewielkiego zmniejszenia ugięcia. Niemożliwe staje się zatem zminimalizowanie wielkości przemieszczeń do oczekiwanego poziomu znacznie poniżej $1 \mathrm{~mm}$. Niemniej jednak przedstawione wyniki analiz za pomocą MES pokazują, że zaprezentowana konstrukcja pozycjonera może nosić cechy optymalnej. Odkształcenia ramienia w kształcie litery „L" są niewielkie, a wyznaczone przemieszczenia wynikają głównie z odkształcenia płyty łączącej ramię pozycjonera z korpusem. Istotne jest, aby po obciążeniu pozycjonera zadaną masą za każdym razem element ten był zorientowany tak samo w przestrzeni, przez co ugięcie ramienia nie będzie mieć istotnego wpływu na pozycję, przy założeniu, że masa elementu nie zmieni się. Mając to na uwadze podczas opracowywania procesów spawania wykorzystujących pozycjoner zintegrowany z robotem, należy mieć świadomość problemów wynikających ze znacznego przemieszczenia ramienia pozycjonera w przypadku dużego obciążenia. Przedstawiona w pracy analiza MES zachowania się pozycjonerów spawalniczych typu-L pod zadanym obciążeniem wskazuje na szereg uwarunkowań przy projektowaniu ich konstrukcji, których efektem będzie określony rozkład naprężeń i odkształceń w konstrukcji czy też wielkość ugięcia poszczególnych zespołów pozycjonera w aspekcie jego pracy na stanowisku zrobotyzowanym.

\section{Praca zrealizowana została w ramach projektu nr POIR.01.01.01-00-0271/16, 2014-2020 NCBiR}

\section{Literatura}

[1] Golański D., Cegielski P., Kolasa A.: Analiza numeryczna odkształceń w elementach konstrukcyjnych podwieszonego toru jezdnego, Zeszyty Naukowe PW, Seria Mechanika pt.: Spajanie materiałów we współczesnej technice, z. 230, 2010, s. 61-69.

[2] Cegielski P., Golański D. i inni: Modelowanie i wdrożenie wysięgników do lokomocji robotów przemysłowych, Przegląd Spawalnictwa 1/2015, s. 6-13.

[3] Cegielski P., Golański D. i inni: Nowe konstrukcje i metody projektowania zewnętrznych osi do lokomocji robotów przemysłowych, PAR 7-8/2013, s. 90-95.

[4] Cegielski P., Golański D., Kolasa A., Sarnowski T.: Nowe konstrukcje i metody projektowania zewnętrznych osi robotów przemysłowych. Problemy Robotyki. T.1, Prace Naukowe, Elektronika, Z.175. OW PW, Warszawa 2010, s. 263-274.

[5] Cegielski P., Golański D., Kołodziejczak P. Kolasa A., Sarnowski T.: Studium rozwiązań konstrukcyjnych nowej generacji zewnętrznych osi robotów przemysłowych, Przegląd Spawalnictwa 11, 2017, s. 84-92.
[6] Cegielski P., Kolasa A., Sarnowski T.: Nowe konstrukcje pozycjonerów jako zewnętrznych osi robotów przemysłowych, Przegląd Spawalnictwa $1,2016$.

[7] Golański D., Cegielski P., Giżyński P., Kolasa A.: Modelowanie numeryczne ugięcia podstawy robotów przemysłowych, Przegląd Spawalnictwa 6, 2014, s. 34-41.

[8] LUSAS Modeller User Manual v.14.0. FEA Ltd. UK.

[9] Wniosek o dofinansowanie projektu: Opracowanie i przygotowanie do wdrożenia zestawu innowacyjnych, zewnętrznych osi robotów przemysłowych wspomagających obsługę obiektów średnio-gabarytowych, Program Operacyjny Inteligentny Rozwój 2014-2020. POIR.01.01.01-000271/16 z dnia 2016-07-28. Numer naboru: 1/1.1.1/2016. 